\title{
AFFERENT IMPULSES IN THE DEPRESSOR NERVE
}

\author{
MASAYASU SATO ${ }^{1}$ \\ Physiographical Science Research Institute and Physiological \\ Laboratory, Medical Department, Tokyo University \\ AND \\ ICHIJI TASAKI ${ }^{2}$ \\ Tokugawa Biological Institute and Physiological \\ Institute, Keio University
}

Bronk and Stella (1932 and 1934) recorded the afferent impulses from the single pressoreceptor in the carotid sinus nerve and their nature and mechanism of blood pressure regulation was fully investigated. But the afferent impulses in the depressor nerve, or in the aortic nerve, which, just as in the case of the carotid sinus nerve, consistute afferent paths of blood pressure regulation, were investigated by Koster and Tschermak (1902), Einthoven (1911), Adrian (1926), Bronk and Kaltreider (1931) and Fischer and Löwenbach (1934) only with whole nerve trunks. They found that bursts of impulses recurring synchronously with each heart beat and with high blood pressure appeared more or less continuously.

In the present work we recorded photographically discharges from a single end-organ of the depressor nerve, thereby obtaining definite information regarding the nature of the activity of the end-organs and their response to pressure.

\section{METHOD}

Rabbits under urethane anaesthesia were used for all of the experiments. On one side of the neck the depressor nerve was freed from the surrounding tissue. The nerve was cut at the central portion. The operation to cut through all but one or several active fibers was conducted at a point 1 to $2 \mathrm{~cm}$. from the cut end. The site of the operation was illuminated with a special illuminating apparatus situated below. The diameter of the nerve fiber was examined in situ under a specially adjusted microscope. The cotton wool soaked in Ringer and placed on the wounded neck of the rabbit was grounded. The cut end of the nerve was suspended in air and connected to the grid of the amplifier, the contact being secured with a silver plate electrode of $1 \times 3 \mathrm{~cm} .{ }^{2}$ in size. In order to show the relation between the afferent impulses and the heart beat, the baseline of the oscillogram was generally distorted by the ECG. Duddel type of electromagnetic oscillograph and Braun tube oscillograph were used for recording the impulses. The change of the blood pressure from the carotid artery of the

1 佐藤昌康

2 田崎一二

Received-for publication September 15, 1950.

Read before the 26th general meeting of the Japanese Physiological Society, May 1949. 
opposite side was recorded at the same time on the electromagnetic type oscillograph, transforming the pressure change into an electric change through two carbon plates connected to a cannule, that was inserted into the artery.

\section{RESULTS}

The discharge from single end-organs. Histological studies on the depressor nerve have been made by Sarker (1922). This nerve is known to comprise mediumsized and fine myelinated fibers and non-myelinated fibers. Most of them are between $4 \mu$ and $6 \mu$ in diameter, but two or three fibers of about $8 \mu$ were also found. In our experiments, impulses from the pressoreceptors were, generally, recorded from fibers of about 4 to $6 \mu$ in diameter.

Fig. 1 is a typical record from such a preparation and is characteristic of the discharge from a single end-organ with normal blood pressure. It will be

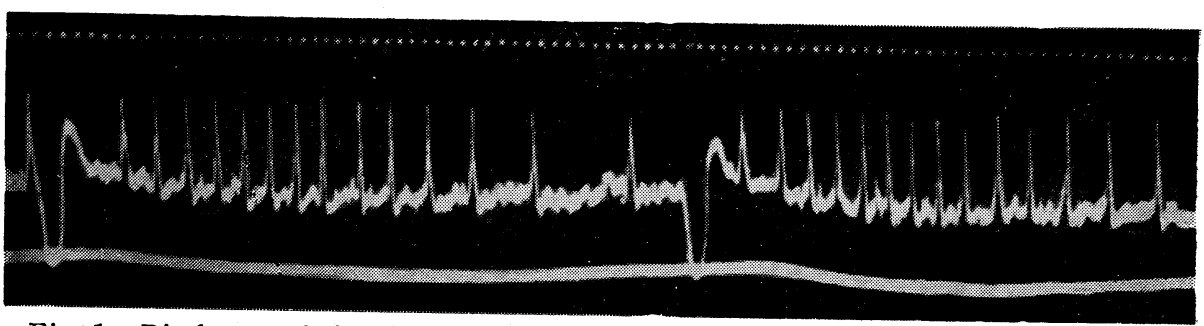

Fig. 1. Discharge of the single nerve fiber of the depressor nerve with normal blood pressure. The large spike is the ECG. The lower curve is the blood pressure curve, where the downward deflection indicates increase of the blood pressure. Each interval of the time marker repersents $1 / 100$ second.

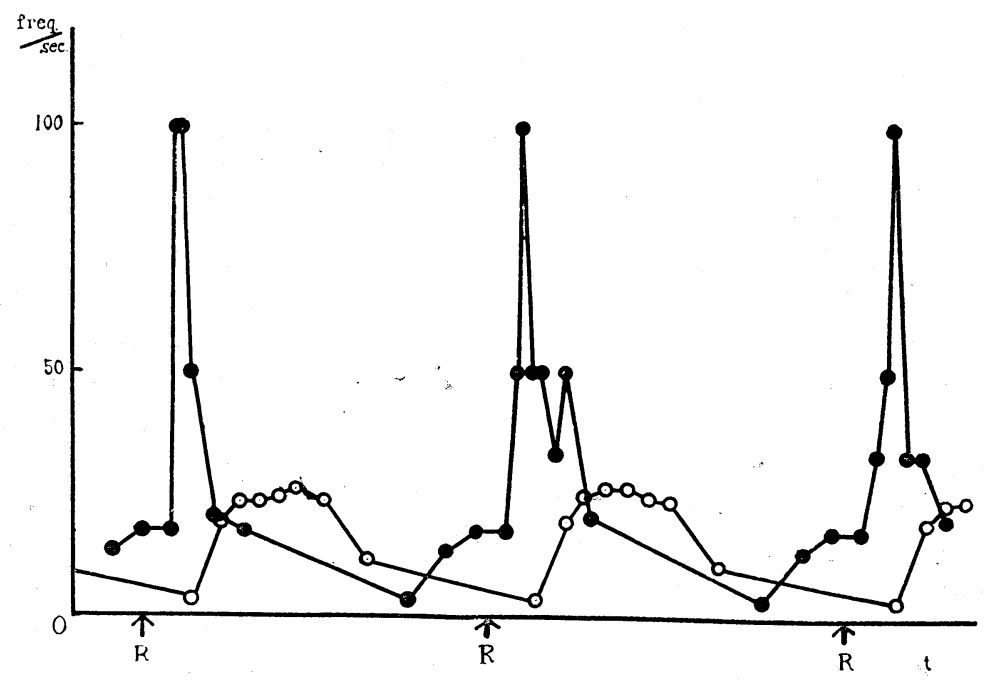

Fig. 2. Changes in the frequency of the two different types of discharges in normal blood pressure. The frequency of the discharge per second was plotted (ordinate) against the time in an arbitrary unit (abscissa). $R$ represents the time corresponding to the ECG. The empty circles were enumerated from the figures same as that in fig. 1 and solid circles from that in fig. $3 \mathrm{~A}$. 


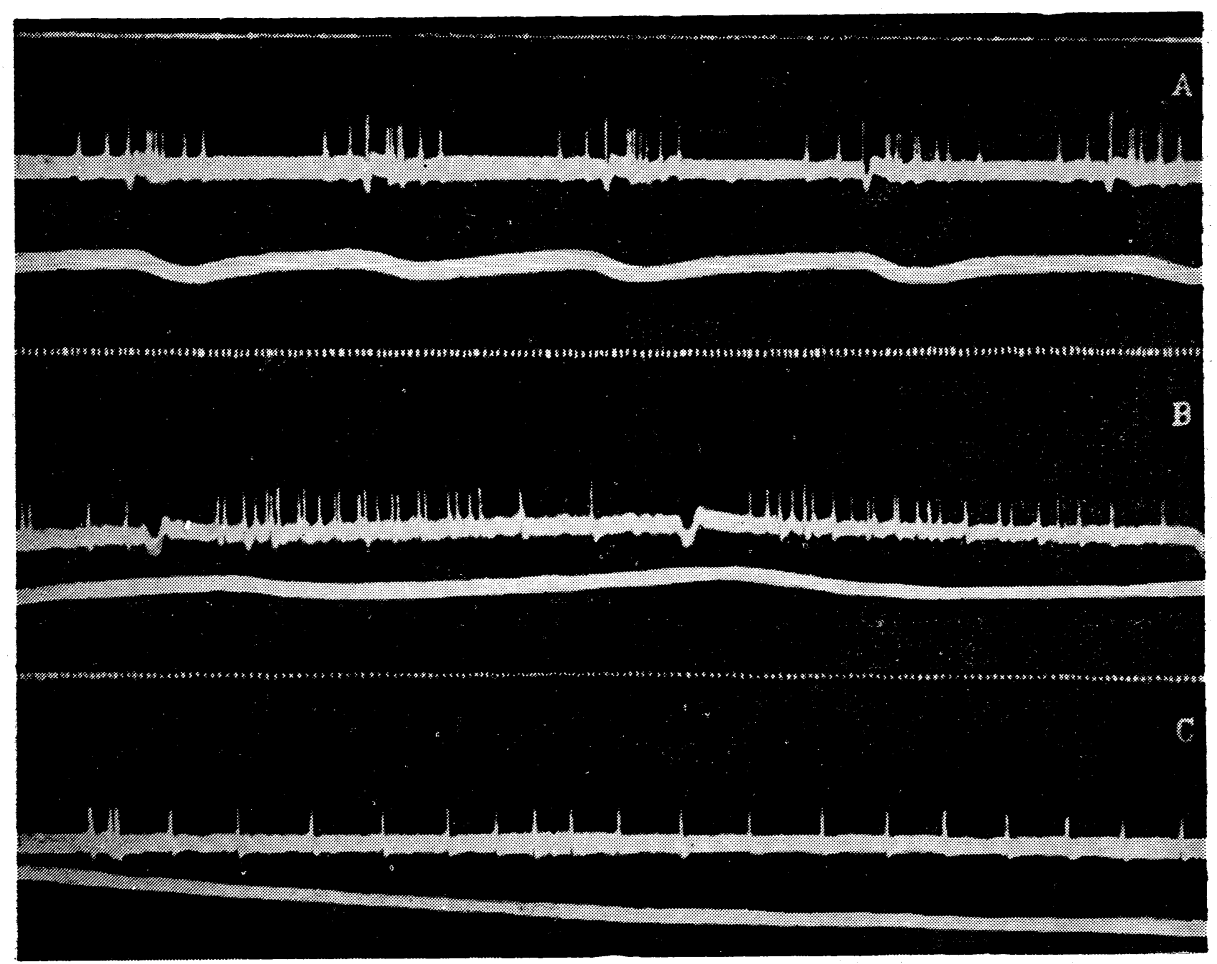

Fig. 3. Discharge of another type of the single nerve fiter of the depressor nerve. The thick spike is the ECG. Blood pressure curve and time marker are the same as in fig. 1, only in fig. 2C the downward deflection of the blood pressure curve indicates the decrease of the blood pressure. A, B and C in this figure were recorded from the same preparation.

A : Discharge under normal blood pressure. The spikes superposed on the QRS-complex of the ECG are also recognizable in this fgure. B: Increase of discharge and number of active units after an intravenous injection of adrenalin. C: Decrease of discharge after an intravenous injection of acetylcholine. It will te seen that another type of fiker comes into action.

observed that the impulses start with the beginnig of systole, increase their frequency, reach the maximum and then decrease, or again increase its frequency a little (fig. 3A). In fig. 2 the reciprocal of the interval between successive impulses is plotted throughout the course of a heart cycle for two different units and shows that one comes into action for a time, whereas the other continues throughout the cycle. As in the carotid sinus nerve (Bronk and Stella, 1932), the main factors for determining the effectiveness of a stimulus for these endorgans may be the absolute level of the blood pressure and its rate of change. The difference in the receptors stated above may be attributable to the difference in the adaptation of the receptors. This is in accordance with the behaviour of the other end-organs such as the carotid sinus (Bronk and Stella, 1932) and the one recorded in fig. 1 may be from the receptor adapting more slowly than that in fig. $3 \mathrm{~A}$.

In the record furnished in fig. $3 \mathrm{~A}$, the existence of another type of receptor, 
the discharge of which was superposed on the QRS-complex of the ECG, is also shown. Such impulses as was superposed on the QRS-complex of the ECG were also found in afferent impulses in the vagus nerve of the cat by Tasaki (unpublished work), who located the receptor near the origin of the aorta in the heart. However, in the event of the cardiac cycle, the maximum of the auricular blood pressure corresponds approximately to the QRS-complex of the ECG (Hoff, 1949). It is therefore supposed that these receptors are located in the auricles and that they come into action by the change in the auricular blood pressure.

Effect of adrenalin and acetylcholine. When $0.5 \mathrm{cc}$. of $0.1 \%$ adrenalin was injected into the ear vein of the rabbit and a transient rise in the blood pressure was made to appear, the duration of discharge per systole became greater, the frequency of discharge also became greater and the number of active units was increased, as was already observed by Bronk and Stella (1932) in the carotid sinus nerve. Fig. $3 \mathrm{~B}$ is one of such examples of adrenalin effect. If the pictures in fig. $3 \mathrm{~A}$ and $3 \mathrm{~B}$, which are of the same preparation consisting of a few fibers, are compared with each other, it will be observed in fig. 3B that the discharge and frequency increased until the discharge continued throughout the heart cycle and another active unit came into action with it.

On the contrary, when the blood pressure was lowered by injecting acetylcholine into the ear vein, the discharge, frequency of the spikes and number of active units decreased, until finally these spikes disappeared and another kind of impulse was found to appear with a slow and constant frequency of about 10 per second (fig. 3C). Again when the blood pressure was restored to normal, the latter disappeared and the former reappeared. Therefore, it may be supposed that there exists some receptor, though their number is very small, which comes into action only when the blood pressure is lowered.

\section{DISCUSSION}

In our experiments it has been shown that the depressor nerve conducts impulses to the center at all blood pressure levels found in normal animals and also that the number and frequency of impulses follow variations in the arterial pressure. Changes in the form of the pulse wave are reflected in the character of the nerve discharge. Bronk and Stella (1932) have reported variations in nerve discharge due to respiratory waves of blood pressure. In the course of this experiment, on one preparation, impulses of about 20 cardiac cycles were photographed continuously with the long recording camera, with the hope of finding fluctuations in impulses due to respiratory changes in the blood pressure. The irregular and small fluctuations in number and frequency of the impulses in each heart beat were, of course, found, but a regular change in nerve discharge corresponding to the respiratory change of the blood pressure was not found. But this is not a clear evidence that the changes in the nerve discharge corresponding to respiratory changes in blood pressure do not exist in the normal depressor nerve. Their absence in this case may be attributable to the weakening of this animal by the operation. 
The conception of afferent depressory fibers located in the heart itself is found in the work by von Bezold and Hirt (1867). Later Jarisch and coworkers (Jarisch and Richter, 1939, Jarisch, 1940, 1941, Amann, Jarisch and Schaefer, 1942, Jarisch and Zotterman, 1948) definitely proved that the afferent impulses runnig upwards in the vagus of the cat originated from the heart itself, namely from the auricles, caval vein and pulmonary veins. On the other hand, through histological examinations, Nonidez (1935, 1941), Pannier (1940), de Palumbi and Verga (1941) and Seto (1937) found in the auricles of both cat and man afferent nerve endings which are very similar to those described by de Castro in the walls of the carotid sinus and the aorta at the depressor region. It is certain that the spikes superposed on the QRS-complex of the ECG is supposed to correspond to those from such receptors. Furthermore histologically, Seto (1937) found two types of pressoreceptors in the sinus and in the arch of the aorta, one having a terminal plate and the other without. Whether these two types of receptors correspond to the receptors described above is not certain.

Special attention to the discharge from the chemoreceptors was not paid in these experiments. But careful investigation on the discharge of single nerve fiber will bring out clearly the mechanism and function of the chemoreceptor reflex.

\section{SUMMARY}

1. Afferent impulses from one more pressure receptor in the depressor nerve of the rabbit have been recorded simultaneously with the arterial blood pressure and ECG.

2. There is a discharge of impulses at all pressure levels in the normal living animal.

3. The degree of activity of the end-organs varies with the blood pressure and is to a considerable extent dependent upon the variations in pressure during the heart cycle.

4. The impulses from a single end-organ are at a maximum frequency during systole.

5. As the pressure increases a larger number of end-organs come into play, the impulse frequency in a single nerve fiber increases, and the discharge continues throughout the greater part of the cycle.

6. Four types of receptors were found. The first responds rather to the absolute value of the blood pressure, the second rather to the rate of pressure change, the third responds when the blood pressure falls and the fourth is superposed on the QRS-complex of the ECG.

\section{REFERENCES}

1. Adrian, E. D. J. Physiol. $61: 49,1926$.

2. AMANN, A., JARISCH, A. AND SchaEfer, H. Die Naturwissenschaften 20: 20, 1942 , quoted from Jarisch and Zotterman (1948).

3. Bronk, D. W. AND Kaltreider, N. L. Am. J. Physiol. $97:$ 508, 1931.

4. BRONK, D. W. AND Stella, G. J. Cell. Comp. Physiol. 1 : 113, 1932.

5. Bronk, D. W. AND Stella, G. Am. J. Physiol. 110: 708, 1934. 
6. Einthoven, W. Verh. d. Ges. d. Naturf., quoted from Bronk and Stella (1932).

7. Fischer, M. und Loewenbach, H. Pfl. Arch. ges. Physiol. $233: 722,1934$.

8. Hoff, H. E. A Textbook of Physiology, edited by J. F. Fulton, Chapt. 31: 609, 1949.

9, JARISCH, A. AND RICHTER, A. Klin. Wschr. 185, 939, quoted from Jarisch and Zotterman (1948).

10. JARISCH, A. Arch. f. Kreislaufforsch. $7: 260,1940$, Klin. Wschr. 1045, 1941, quoted from Jarisch and Zotterman (1948).

11. JARISCh, A. AND ZotTerman, Y. Acta Physiol. Scand. 16: 31, 1948.

12. Koster, G. AND Tschermak, B. Pfl, Arch. ges. Physiol, $93: 24,1902$.

13. Nonidez, J. F. Am. J. Anat. $57: 259,1939,68: 153,1941$, quoted from Jarisch and Zotterman (1948).

14. PALUmbi, E. AND Verga, E. Bull. Soc. Ital. Biol. Sperimt. $16: 715,1941$, quoted from Jarisch and Zotterman (1948).

15. PANNIER, R. Arch. int. Pharmacodyn. $64: 276$, 1940, quoted from Jarisch and Zotterman (1948).

16. SARKER, B. B. Proc. Roy. Soc. Lond. B, $93: 230,1922$.

17. SETo, H. Arbeiten aus Anat. Inst. d. Kaiserl.-Jap. Universität zu Sendai 20 : 1, 1937.

18. Von Bezold, A. AND HIRT, A. Unters. Physiol. Lab. in Würzburg 1: 95, 1867, quoted from Jarisch and Zotterman (1948). 